\title{
The Sphere of Values and Meaning of a Person and its Role in Professional Formation and Development
}

\author{
Anzhela V. Romanova1, Galina S. Goloshumova ${ }^{2}$, Maksim V. Belousov ${ }^{3}$, Alla V. Ignatyeva ${ }^{4}$, \\ Zhanna V. Korobanova ${ }^{5}$, Natalia A. Krasheninnikova ${ }^{6}$, Patimat Sh. Alieva ${ }^{7}$ \\ ${ }^{1}$ Department of Social, General and Clinical Psychology, Russian State Social University, Moscow, Russian Federation \\ ${ }^{2}$ Department of Pop-Jazz Art, Moscow Pedagogical State University, Moscow, Russian Federation \\ ${ }^{3}$ Institute of Psychology and Education, Russian New University, Moscow, Russian Federation \\ ${ }^{4}$ Department of Decorative Art and Design, Moscow City University, Moscow, Russian Federation \\ ${ }^{5}$ Department of Personnel Management and Psychology, Financial University under the Government of the Russian Federation, Moscow, Russian \\ Federation \\ ${ }^{6}$ Department of the English Language for Professional Activities, Ulyanovsk State University, Ulyanovsk, Russian Federation \\ ${ }^{7}$ Department of Humanitarian and Socio-Economic Disciplines, North - Caucasian Institute (Branch) of the All-Russian State University of Justice \\ (RLA of the Ministry of Justice of Russia), Makhachkala, Russian Federation
}

Received: 18/07/2020

Accepted: 03/09/2020

Published: 20/12/2020

\begin{abstract}
The current stage of development of Russian society is characterized by rather intense and serious socio-economic, industrial, legal and spiritual-moral changes. These changes, due to the characteristics of mental development, have the greatest impact on the personality of young people and their behavior. The paper considers the problem of the value orientation of contemporary youth in Russia. The psychological characteristics of the person have been determined, in relation to which various value orientations are formed from the point of view of E. Fromm's concept, and their role in vocational formation. The authors have proved the integrity, the integration of the value system with other personality characteristics, as well as the differences in individuals regarding the orientation to "Being" or "Possession". The conclusions have been drawn that the nature of the value orientation of young people in contemporary Russia is complex. Values are divided into blocks according to the spheres of human life and are subject to the more general law of their dominant orientation - "Being" or "Possession". Accordingly, the nature of personality orientation determines the formation and development of value groups.
\end{abstract}

Keywords: Value orientation, Youth, Personality factors, Social character, Modes of existence, Professionalism, Innovative potential of Russian youth

\section{Introduction}

The current stage of development of Russian society is characterized by rather intensive and serious socio-economic, industrial, legal and spiritual-moral changes [1,2]. Scientific and technological progress, the increasing role of information in human life and the intensification of the rhythm of life of contemporary man can be called the main features of these changes. In the changing and increasingly complicated living conditions, a person has to constantly adapt to new conditions, including in the professional sphere [3-14]. In accordance with this, at the present stage, the system of vocational education is based on the ideas of the development of key personal competencies. As a rule, many authors distinguish various competencies, but in general one can note the universal ones professional and social. The success of a person's adaptation from the point of view of the competency-based approach assumes their development and enrichment with various skills and personal abilities that will allow him to perform subsequent activities effectively.
This is of particular importance for young people who are specialists-beginners. Firstly, they are faced with the problem of successful employment. By the way, at the moment, youth have significant problems with employment. According to the Federal State Statistics Service, 20\% of graduates do not find work in the first year after graduation. According to the results of monitoring the state of the labor market, the Ministry of Education and Science of Russia provides the following information: $11 \%$ of graduates of higher professional institutions are at risk of being unemployed, their percentage among graduates of secondary professional institutions is 10 Secondly, taking into account the orientation of the youth policy of the state towards the innovation course, it is young specialists who should be the innovative resource of Russia. This idea suggests that young professionals must successfully carry out their professional activities, as well as realize their abilities in the framework of research, social and economic projects that contribute to the development of the economic and scientific potential of Russia [15-18]. A review of published scientific works shows that at present, the preferred attention both in practical educational activities and in research works is

Corresponding author: Natalia A. Krasheninnikova, Department of the English Language for Professional Activities, Ulyanovsk State University, Ulyanovsk, Russia. E-mail: kna.73@mail.ru 
paid to the professional and social blocks of personal competence [19]. But, on the other hand, for a more complete realization of his professional potential, a person needs to be active, initiative, willing to take risks, use creative and intellectual resources of the person, and also interact with the surrounding society. In addition, social interaction skills characterize the success of professional activities, especially in the field of professions "person-person" [20 - 29].

As you can see, the former professional competencies and state support are far from being the guarantee of successful employment and the effective implementation of their resources. Despite the measures taken and the high rates of professional competence, young people continue to experience difficulties in finding work, in the implementation of their project and research work. This issue was noted by N.K. Chapaev [30, 31]. In his opinion, in the framework of the development of main competencies, a skillful approach is implemented, which includes the development of competencies of specific knowledge and skills, as well as skills for successful presentation of oneself to the employer [32]. Thus, from the point of view of this approach, a person is gradually split, from a holistic personality to a carrier of a set of professionally important characteristics without the desire for selfimprovement and self-development. In the light of what has been said, it becomes clear that it is also necessary to study the competence associated with the development of the "self". This competency was identified by the Council of Europe, in particular by Walo Hutmacher [33]. It is it that contains the position of the active "I" of the subject of professional activity. This position is the bearer of such personality characteristics as life strategies, life-meaning orientations, value orientations. They affect professional activity, characterize its style, quality, purpose and development paths.

In our opinion, one of the key categories in this competency is value orientation, since it has a significant impact on the formation of social competence and on the position of the subject of professional activity, especially a young specialistbeginner. The applied character of the category of value orientation is manifested in its integrality and multidimensional influence on the personality in general, the professional in particular. The value orientation in its definition reflects significant, key values, goals, motives and other characteristics of the value and motivational sphere, which, in turn, are integrated into complex schemes. In the context of professionalism, it is important by the fact that it fills the subjective position of the person with concrete content [34]. This subjective position determines the career guidance of the person, the system of its professional views and skills, the direction of development of the personality of a professional. In a sense, value orientation can be described as an engine for the development of a professional, not only as a high-quality specialist, but also as a socially responsible and personally determined subject of professional activity. It is the complete, harmonious development of all these areas that determines the formation of a professional and contributes to the development of the innovative potential of young people [35 -39]. Accordingly, the study of these characteristics should also be implemented as part of the value-integrated approach. However, in the analysis of recent studies on the problem of value orientation, we can mainly find research programs focused on obtaining information only about the prevalence of any values over others, as well as attempts to establish a relationship of a particular single value with any psychological trait. Such an approach, postulating discreteness of the value and value orientation, represents value orientation in the form of a closed, rigidly fixed system. Such a system is not capable of possessing signs of integrality and continuity of functioning.
In addition, the nature and essence of the value is not disclosed. It indicates only its social conditioning and significance for the individual. However, these characteristics are quite superficial in nature, especially since too many categories fall under them. As a result of this, it is often difficult, and sometimes impossible, to separate the value itself and other categories of personality, such as motive, need, etc. [40 - 44].

As P.I. Smirnov [45] points out, the value cannot exist by itself, separated from the world and man, nor can it be only socially conditioned and characterized only by the degree of abstract significance. The value is, first and foremost, an incentive to activity, both external and internal one. Something is valuable which efforts are made for, what is the goal. In addition, value cannot exist in a single form; usually it forms a system with other values. Throughout the past century, several attempts have been made to derive a number of fundamental, universal values. However, the models were built on the classification of all existing specific values, which led to their ambiguity and methodological problems in research. The value in this approach, in short, was significant for everyone in general and at the same time few for anyone specifically in its embodiment in the life of an individual. Therefore, for the effective study of value orientation, it is necessary to develop a different approach. In recent years, the implementation of new approaches to the study of values has been undertaken by social psychologists, sociologists, and philosophers. All of them have different theoretical bases and methodological principles.

\section{Methodological Framework}

In our opinion, it is more efficient to consider the value orientation in the context of deep orientation proposed in the works of the German sociologist and social psychologist E.Z. Fromm [46]. According to his conception, a person's life strategy is determined by his social character, specific deep orientation, which comprises a number of integrated parameters. These orientations are called "To Be" and "To Have." As V. Dobrenkov [47] points out, Fromm thinks of the development of society as a system with two poles; on one of them is a social character, designed to stabilize a person's position in society, on the other - human nature, which creates social conditions. In the framework of this school, value is presented to us as part of this deep orientation, or, as mentioned above, the ultimate goal of existence. However, along with the orientations "To Be" and "To Have", E. Fromm introduces the concept of "Existential possession". E. Fromm [46] defines this category as a rationally determined desire for self-preservation, which does not contradict the nature of "To Be". The appearance of the construct "Existential possession" in Fromm's concept poses the question of what positions the modes of "To Be" and "To Have" identified by him should be considered from [46]. Theoretical and methodological analysis of Fromm's work regarding the modes of "To Be" and "To Have" allows us to state that in his works there is no description of the role and place of the construct of "Existential possession" in the context of the modes of human existence.

Studying the phenomenon of "Existential possession" we can assume that it can be placed between two bipolar poles, one of which is the principle of "To Be", and the other is the principle of "To Have". However, with this approach, we encounter a rather simplified understanding of the combination of the modes "To Be" and "To Have", or rather, with the understanding of the impossibility of any combination of them. With a continuous location, it turns out that a person can only be assessed as realizing himself in accordance with one of the poles: either in accordance with the principle of "To Be", or in accordance with the principle of "To Have". In this case, "Existential possession" is a kind of compromise between these 
principles, the result of their blending, and such a result that does not allow a high degree of intensity of expression of both of the poles at the same time. At the same time, another understanding of the combination of the modes "To Be" and "To Have" is possible which, in our opinion, is more consistent with reality than its reduced consideration from the standpoint of the bipolar-continuum approach. In this case, we are talking about the possibility of considering the modes of "To Be" and "To Have" as independent quantities, or, speaking differently, from the standpoint of the orthogonal approach. In this case, the vectors reflecting the name of these modes should be located on a plane perpendicular to each other. However, then the opposite mode should be the mode "Not to have" and the opposite of the mode "To Be" should be the mode "Not to be". Finding the meaning of these modes is not a simple psychological task, however, clarification of their essence allows us to comprehend a certain range of phenomena of social reality, which have been discussed for a long time by both the press and specialized scientific publications [48]. Indeed, if a person does not possess anything, is it possible to speak with confidence that, in this way, he is oriented to the mode "To Be"?. Experience shows that this is not necessary at all. The continuum of "Possession" is represented at one pole by the desire to "have" as much as possible, at the other by the rejection of possessing something (including one's own life). The continuum "To Be" as a category of love of life and true involvement in the world, the true reality of a person, in contrast to a deceptive appearance, is more or less definite.

The meaning of "Not to be" is represented as the absence of the existence of the individual. But if to reason from this position, then the very existence of the individual implies "Being". Therefore, it seems logical to get away from the usual understanding of "non-existence" and shift the emphasis from clarifying its philosophical essence to the person's desire to implement the mode "Not to be" in his psychological sense. Thus, it is possible to distinguish not two, but four variations of the modes of existence: "To be" - "To have", "To have" - "Not to be", "Not to be" - "Not to have", "Not to have" - "To be".

The understanding of "Existential possession" can be defined as follows. The region located within its boundaries over the vector "To Be" logically fits into the problems of existential choice, one of the options described by I. Yalom [49] in his work. Making a choice in one of the available alternatives, we at the same time "do not choose" another alternative. However, we bear the same responsibility for this "not a choice" as for the made "choice". In other words, the very act of choice speaks of us as creatures who, having taken a step towards the mode of "To Be" to some alternative, if the true choice was really made by the individual, at the same time we choose "Not to be" with respect to rejected alternatives. "Existential possession" in the direction of the vector "To have" implies the presence of its opposite "Not to have" [48].

Fromm's conception of the social character and orientation of the personality was continued by his assistant and student R. Funk [40]. Having studied the social character of contemporary German youth, in addition to the original concept, he added a type of social character such as "I-am-me" orientation [50]. The essence of this orientation consists in the fact that a contemporary person wants to create his own reality that "bears the imprint of his personality". As the author himself defines, a person lives under the slogan "Until you have done something, you are nothing". The emergence of this type of social character may indicate that one of the priorities for a contemporary person is the construction and presentation of his self, his life world. In this type of social character, two tendencies can also be found: striving for possession or the desire for being. R. Funk [50] considers the desire for possession as a passive type of character, in a sense echoing the receptive social character in E. Fromm's [51] conception. The passive type can be characterized as a person incapable of constructive building his own reality, but only adopting this reality from other individuals [52 - 55]. In a way, it is like consumption, a consumer type of social character. The difference is what is consumed: before it was things, status, social roles, now it is the whole life worlds of individuals, which include many attributes. In domestic psychology, the development of the problems of E. Fromm's school of thought is also underway [51]. For the most part, sociologists and social psychologists deal with this problem. In our work, based on E. Fromm's works, an attempt was made to determine the psychological content of the modes of being and possession, as well as their relationship with some personality factors [51].

The purpose of this study is to show the integrity, the integration of the value system with other personality characteristics, as well as the differences in individuals relative to the orientation towards being or possession. In addition, E. Fromm's thoughts on the position of training in a particular mode are important. From his point of view, there are two types of knowledge: according to the principle of being - to know more deeply; to the principle of possession - to have more knowledge [51]. Thus, knowledge, no matter how vast it can be, should be associated with the activity of the individual, his life position.

\section{Materials and Methods}

The study was conducted at Russian State Social University, Moscow Pedagogical State University, Russian New University, Moscow City University, Financial University under the Government of the Russian Federation and Ulyanovsk State University. The research sample was 500 3-4year students of various programs of study in the framework of the professional system Person-Person": jurisprudence, sociology, social work, personnel management, customs. In the course of the study, the following techniques were used: "Value Orientations" by M. Rokeach [56]; R. Cattell's [57, 58] 16-PF factorial personality questionnaire; the developed methodological technique for splitting the sample according to the type of dominant mode of existence. At the moment, there are a number of techniques that diagnose one or another characteristic of a mode, for example, A.V. Puzyrev [59], diagnosing the degree of biophilia - personality necrophilia. However, these techniques are designed to study the individual properties of modes or attitudes of a person [60]. Therefore, we designed a questionnaire that reflects several basic characteristics of the mode of being and possession, interconnected and reflecting the essence of the mode.

\section{Results and Discussion}

According to the results of the study, the following data was obtained: there is a significantly significant difference with respect to the dominant mode of existence for such psychological factors of personality as emotional maturity and level of self-esteem. Also, at the significance level of five percent there is a difference in the factor of restraintexpressivity. This means that people oriented to the mode of possession are characterized by low emotional maturity, low self-esteem, and excessive restraint. Accordingly, we can characterize a person with a dominant mode of possession as an emotionally immature, lethargic, infantile, constrained individual with rigid patterns of behavior and an unstable emotional background who is afraid of responsibility, independent decision-making, risk. A low level of self-esteem contributes to the self-limitation of the use of one's abilities and 
skills, and also on this basis blocks the development of emotional maturity and a holistic harmonious subjective position. The obtained data on the difference in the psychological traits of individuals with respect to the dominant mode of existence represent, in a sense, an active and passive type of character in the conception proposed by R. Funk [50]. Low emotional maturity, as well as low self-esteem can contribute to the formation of a receptive character.

The analysis of differences in values relative to the mode of existence showed the following data: there are differences in the field of terminal values relative to the mode of existence for the following individual values: productive life, cognition, pleasure. According to the results, the more a person is oriented to the mode "To Have", the lower the values of cognition and productive life are. It is also possible to say that the more a person is oriented to the mode "To Have", the higher the rank of the value of pleasure is. In the framework of the problem of realizing the potential of a specialist-beginner, this can be considered as an orientation of a person with a dominant mode of possession towards obtaining the maximum amount of shortterm pleasures and a lack of desire for learning, selfdevelopment, realization of one's own natural potential, as laid down in E. Fromm's theory. At the same time, the presence of two highly significant values in the structure of the mode of being - cognition and productive life - suggests that "being cognition is really associated with the activity of the individual. The values themselves indicate dynamic content, cognition as a process, productive life - activity in time. Regarding instrumental values, there are differences in the level of tolerance, high demands and sensitivity. That is, the higher the orientation towards the mode "To Have", the higher the value of tolerance is, and vice versa, the lower are the values of high demands and sensitivity.

Thus, the value of high requests indicates a positive assessment of oneself, one's abilities and expresses the willingness and desire of the individual to realize them in the framework of professional activities and other areas of life, while a person oriented to the mode of possession is afraid to claim such a high level of requests, assessing his capabilities inadequately low. Perhaps, due to these characteristics, a person with a dominant mode of possession has a more significant value of tolerance, it is with the help of it that he compensates for an inadequate perception of himself and his capabilities and realizes his professional abilities on the basis of complete patience and diligence. The value of sensitivity and its low rank in an individual oriented to the mode of possession can have a link with emotional immaturity. Since the meaning of sensitivity is attentiveness to other people, a person with the characteristics of possession cannot and does not want to realize it because of his incredulity and anxiety.

\section{Conclusion}

The results of the study allow us to conclude that the nature of the value orientation of young people in contemporary Russia is complex. Values are not simply split into blocks according to the spheres of human life, they are subordinate to a more general law of their dominant orientation - being or possession. Accordingly, the character of the personality orientation determines the formation and development of value groups. In addition, based on the results of the study, we compiled a generalized psychological portrait of the individual who is oriented to the mode of possession or being as a way of existence. Based on this portrait, one can create a program for the correction of vocational guidance and the development of professional motivation of students - future specialists. The ultimate goal of this program is to promote successful employment and the development of an active subjective position of a young specialist. This program involves working with individuals oriented to the mode of possession to develop their respective values and psychological characteristics that characterize individuals oriented towards a productive type of social character. It is also important to note that the practical implementation of the results of this work, its elements will help specialists working with youth to solve a number of issues related to the development of professionalism, an active subjective position and, ultimately, with more successful adaptation, which will qualitatively raise the level of innovative potential of young people in Russia.

\section{Ethical issue}

Authors are aware of, and comply with, best practice in publication ethics specifically with regard to authorship (avoidance of guest authorship), dual submission, manipulation of figures, competing interests and compliance with policies on research ethics. Authors adhere to publication requirements that submitted work is original and has not been published elsewhere in any language.

\section{Competing interests}

The authors declare that there is no conflict of interest that would prejudice the impartiality of this scientific work.

\section{Authors' contribution}

All authors of this study have a complete contribution for data collection, data analyses and manuscript writing.

\section{References}

[1] Kayumova LR, Morozova MA. Using the technology of critical thinking development (CTD) as a means of forming competencies of students majoring in "life safety". International Journal of Environmental and Science Education.2016;11(8):2113-2122.

[2] Krutikhina MV, Vlasova VK, Galushkin AA, Pavlushin AA. Teaching of Mathematical Modeling Elements in the Mathematics Course of the Secondary School. EURASIA Journal of Mathematics, Science and Technology Education.2018;14(4):1305-1315.

[3] Salakhova VB, Zaretskiy VV, Kalinina NV, Artamonova EG, Efimova OI, Lekareva EE. Existential psycho-correction of the value-meaning sphere of the personality of adolescents with deviant behavior. Modern Journal of Language Teaching Methods.2018;8(6):294-302

[4] Romanova AV, Salakhova VB, Ganova TV, Nalichaeva SA, Nazarova LS, Dolzhenko AI. Hardiness as a component for sustainable development of a person's personality: Ecological and psychological aspect. EurAsian Journal of BioSciences.2019;13(2):1833-1840.

[5] Lekareva EE., Zaretskiy VV, Artamonova EG, Salakhova VB, Efimova OI, Kalinina NV. Comprehensive rehabilitation of minors with deviant and delinquent behavior: The experience of the Russian system of education. Eurasian journal of analytical chemistry. Eurasian Journal of Analytical Chemistry.2018;13(1b):em84.

[6] Wang S, Gorbunova NV, Masalimova AR, Bírová J, Sergeeva MG. Formation of Academic Mobility of Future Foreign Language Teachers by Means of Media Education Technologies. EURASIA Journal of Mathematics, Science and Technology Education.2018;14(3):959-976

[7] Kalinina NV. Social and personal resources to overcome difficult life situations. Simbirsk Scientific Journal Vestnik.2011;1(3):96101.

[8] Pomelov VB, Khairutdinova RR, Kryukova NI. Lexical material of regional content in the process of implementing the communicative approach in teaching English to students of nonlinguistic specialties. XLinguae.2018;11(1):136-151.

[9] Efimova OI, Grinenko AV, Kalinina NV, Miroshkin DV, Bazhdanova YV, Oshchepkov AA, Ivleva SA. Personality hardiness as a factor determining the interaction of a person with 
the environment (psychological and ecological aspects). Ekoloji.2019;107:563-569.

[10]Erofeeva MA, Ulyanova IV, Plakhotnikova IV, Kurilyuk YE, Egorov VA, Kochetkov IG. Reforming and developing socialization of children with limited abilities (mild intellectual disability). Electron Journal General Medicine.2019;16(2): em112.

[11] Telysheva NN, Erofeeva MA, Ulyanova IV, Pokrovskaya SV, Nikitskaya EA, Gorokhova IV, Kochetkov IG. Socio-ecological determinants in the deviant behavior formation system. Ekoloji.2019;28(107):5077-5081.

[12] Podymov NA, Nikoghosyan MA, Stolyarova AN, Narutto SV, Mashkin NA, Martynenko SE, Paznikova ZI, Varenik PK. University New Educational Reality in Disruptive Technologies Context. Journal of Environmental Treatment Techniques.2019; 7(4):664-668

[13]Zaitseva NA, Larionova AA, Shapovalov NI, Povorina EV, Takhumova OV, Zhukova MA, Dvornikova TA. Regulatory aspects and problems of personnel certification taking into account the requirements of professional standards. International Journal of Psychosocial Rehabilitation.2020;24(03):2179-2188.

[14] Kayumova LR, Zakirova VG, Sizova ZM, Buslaev SI. Peculiarities of future teachers' training in professional activities in risk settings: Methods and technologies. Talent Development and Excellence.2020;12(Special Issue 3):50-63.

[15] Goloshumova G.S, Ershova OV, Salakhova VB, Kidinov AV, Nalichaeva SA, Yanysheva VA. Information and educational environment of higher school as a factor of the formation of coping strategies in the structure of students' personality (ecological and psychological aspect). EurAsian Journal of BioSciences.2019;13(2):1867-1874.

[16] Mitina ID, Mitin SN. Education as a socio-cultural institute of modern society, Scientific Journal Vestnik.2018;4(34):66-70.

[17] Potapova SV, Danilova IY, Prasolov VI, Makarova EV, Kryukova NI. Mythological foundations of ontology. XLinguae.2018;11(2):672-685.

[18]Butakova MM, Sokolova ON, Zaitseva NA, Larionova AA, Ignatova MN, Trufanova SN, Yakovlev AY. Evolution and current development trends of the Russian federation's higher education system. Opción, Año, 36, Especial No.271718-1733.2020.

[19] Kayumova LR. Formation of the noxologic educational environment in elementary school: Application of moderation technology. Mathematics Education.2016;11(4):779-786.

[20]Minakhmetova AZ, Skutelnik OA, Fedorchuk YM, Shulga TI, Pavlushin AA, Shagiev BV. Motivational and valuable orientation of teachers as a condition to form students' tolerant behavior. Man in India.2017;97(3):323-332.

[21] Erofeeva MA, Stolyarova AN, Evseeva IG, Popova TA, Lobzhanidze AA, Luchenkova MA, Kalinin IV. The development of a safe educational environment at a higher education institution within the framework of the ecopsychological approach. Ekoloji.2019;28(107):5089-5093.

[22] Gemranova AD, Mitina ID. Socio-cultural character of university education, Scientific Journal Vestnik.2018;4(34):54-58.

[23] Davoudi SMM, Fartash K, Zakirova VG, Belyalova AM, Kurbanov RA, Boiarchuk AV, Sizova ZhM. Testing the Mediating Role of Open Innovation on the Relationship between Intellectual Property Rights and Organizational Performance: A Case of Science and Technology Park. EURASIA Journal of Mathematics, Science and Technology Education.2018;14(4):1359-1369.

[24] Martynenko AV. Teacher of higher school: modern challenges, contradictions and prospects of profession. Scientific Journal Vestnik.2019;3(37):19-24

[25] Vasyakin BS, Berezhnaya MS, Pozharskaya EL, Ovsyanik OA. Socio-psychological training in modern health psychotechnological toolkit to improve stress tolerance in academic personnel. Teoriya i Praktika Fizicheskoy Kultury.2018;8:75-76.

[26] Vikhryan AP, Gorohova VV, Gorohova IV, Erofeeva MA, Narbut NP, Puzanova ZhV, Yunusov AM. The methodology aimed at preventing the manifestations of terrorism and extremism among children and youth in the educational environment. Moscow: RUDN.2015.

[27] Goloshumova GS, Albakova ZA, Marchev KV, Kidinov AV, Gustova EA, Salakhova VB, Krasheninnikova NA. The interrelation of environmental and social factors and man's mental health. Ekoloji.2019;28(107):6013-6016.
[28] Grinenko AV, Gegel LA, Poleshchuk IA, Tutaeva DR, Pronina EV, Shchukina TV, Egorova EV. A governing and political orientation in the field of education. Eurasian Journal of Biosciences.2019;13(1):149-154.

[29] Khairullina ER, Bogdanova VI, Slepneva EV, Nizamutdinova GF, Fatkhullina LR, Kovalenko YA, Skutelnik OA. Global climate change: Cyclical nature of natural and permanent nature of manmade processes. EurAsian Journal of BioSciences.2019;13(2):2311-2316.

[30]Chapaev NK. Pedagogical integration: methodology, theory, technology. Ekaterinburg: Publishing House of Ros. state prof. unthat. Kemerovo: Kemer Publishing House. state prof. College. 2005

[31]Chapaev NK, Weinstein ML. Integration of education and production: methodology, theory, experience. Chelyabinsk: CHIRPO.2007.

[32]Education in Russian regions: the scientific foundations of development and innovation. Materials of V All Russian scientific conf., Yekaterinburg, November 23-25. Institution Russian Academy of Education "Ural, department"; SEI HPE "Russian state prof. pedagogical university", pp. 12-14 Yekaterinburg.2009.

[33] Hutmacher W. Key competencies for Europe. Report of the Symposium Berne, Switzezland 27ñ30 March, 1996. Council for Cultural Co-operation (CDCC). Secondary Education for Europe Strsburg. 1997.

[34]Zhgenti IV, Kuznetsova VV, Savinov AM, Gribova OE, Sidyacheva NV, Prokopyev AI. Modern integration processes influence on educator's professional growth. Espacios.2018;39(2):13-23.

[35] Shukshina LV, Bazhdanova YV, Koretskaya IA, Vasyakin BS, Lipatova NV. Development of multicultural value orientations in future specialists in the context of a higher education institution. Eurasian Journal of Analytical Chemistry.2017;12(5);775-885.

[36] Mitina ID. Specificity of determining and forming priority directions of regional cultural policy within the framework of sociology of culture. Simbirsk Scientific Journal Vestnik.2018;3(33):72-77.

[37] Selivanova OG, Gromova CR, Mashkin NA. Improving student motivation for learning the second foreign language XLinguae.2018;11(1):218-229.

[38] Avdeev VA, Avdeeva OA, Shagieva RV, Smirnova VV, Mashkin NA, Taradonov SV. The mechanism of legal regulation in the conditions of globalization and formation of information environment. Regional aspect. Journal of Environmental Management and Tourism.2019;10(7):1517-152.

[39]Zyubina IA, Dzyubenko AI, Borisenko VA, Popova OV, Prokopyev AI. Implicit linguopragmatic strategies of speech behavior of English-speaking prosecutors. XLinguae.2019;12(4):92-102.

[40] Mitin SN, Shukshina LV, Bazhdanova YV, Koretskaya IA, Vasyakin BS. Value and meaning attitudes as a factor of forming tolerant ethnic consciousness in the multicultural milieu of a higher education institution. Eurasian Journal of Analytical Chemistry.2017;12(7):1193-1200.

[41] Salakhova VB, Sidyacheva NV, Zotova LE, Klepach YV, Rusyaeva TA, Belova TA, Buevich SY. Specific features of normative ideals and individual priorities of the deviant personality. Modern Journal of Language Teaching Methods.2018;8(5):232-242.

[42] Kvon GM, Vaks VB, Masalimova AR, Kryukova NI, Rod YS, Shagieva RV, Khudzhatov MB. Risk in implementing new electronic management systems at universities. Eurasia Journal of Mathematics, Science and Technology Education.2018;14(3):891902

[43] Razumovskaya MI, Larionova AA, Zaitseva NA, Petrina OA, Vinogradova MV, Nagay NG, Takhumova OV. Models of integrated interactions organization in the field of environmental education. Journal of Environmental Treatment Techniques.2019;7(4):576-580.

[44] Ovsyanik AI, Sidorenko GG, Prasolov VI, Aleksandrova NS, Mashkin NA, Pozdnyakova IR, Makarova EV. Remote education in modern university: Potential opportunities, quality or availability? International Journal of Psychosocial Rehabilitation.2020;24(4):5027-5034. 
[45] Smirnov PI. Value: the impetus of activity and one of the main concepts of sociology. Theoretical journal Credo new.2011;1: 113125.

[46] Fromm E. To have or to be? Translated by E. Telyatnikov. Moscow: AST. 2011.

[47]Dobrenkov VI. Psychoanalytical sociology of Erich Fromm. Moscow: Alfa-M. 2006.

[48] News of the Samara Research Center of the RAS. Special Edition "Important problems of psychology". Samara: SRC. 2006. URL: http://hpsy.ru/public/x3462.htm.

[49] Yalom I. Existential psychotherapy. Moscow: Independent firm "Class". 1999.

[50]Funk R. The Psychodynamics of the Postmodern "I-am-me" Orientation. International Conference on the Occasion of the 20th Anniversary of the International E. Fromm Society, October 29, 2005, Switzerland. 2005.

[51] Fromm E. The grandeur and littleness of Freud's theory. Moscow: LLC Firm AST Publishing House. 2000

[52] Kalinina NV, Zaretskiy VV, Salakhova VB, Artamonova EG, Efimova OI, Lekareva EE. Psychological and pedagogical resources of security provision and prevention of internet risks and life threats among children and teenagers in the educational environment. Modern Journal of Language Teaching Methods.2018;8(8):118-129.

[53] Efimova OI, Salakhova VB, Oshchepkov AA, Khudyakova TL, Deberdeeva NA. Antisuicidal potential of the person: theory and empirics research. Modern Journal of Language Teaching Methods.2918;8(5):510-517.

[54] Salakhova, VB, Sokolovskaya IE, Ulyanova IV, Karina OV, Terekhova AI. Deviant behavior formation factors among students: aggressive behavior and internet risks. Práxis Educacional.2019;15(34):683-694.

[55] Erofeeva, MA, Grinenko AV, Stanovova LA, Kosolapova NV, Mikhaylovsky MN, Rybina IA, Kochetkov IG. Motivation and motives of juvenile delinquents. Eurasian Journal of Biosciences.2019;13(1):135-140.

[56] Rokeach M. The study of value orientations. psychojournal.ru popular science psychological portal. URL: https://psychojournal.ru/tests/479-issledovanie-cennostnyhorientaciy-m-rokicha.html (Date of treatment April 30, 2020). 2015.

[57]Cattell RB. Structured personality learning theory. New York: Praeger.1983.

[58] Cattell RB. The birth of the Society of Multivariate Experimental Psychology. Journal of the History of the Behavioral Sciences. 1990;26:48-57.

[59] Puzyrev, AV The technique for studying two fundamental origins in psychological attitudes of a person. Bulletin of TSPU.2009;8:112-116.

[60] Mukhametzyanova LY, Aleksandrova NS, Greek AD, Zatsepina MB, Prokopyev AI and Gaidamashko IV. Culture-oriented component scientific and methodical support of students' humanitarian training in university. XLinguae.2018;11(1):230241. 